E-ISSN. 2685-7650

Vol. 1 No. 1 (2019), pp 51-57

DOI: https://doi.org/10.33366/jkn.v1i1.14

\title{
Bentuk Kekerasan pada Sinetron Anak Langit
}

\author{
Jubaidah Berthniastuti Matau', Muchammad. Abdul Ghofur ${ }^{2}$ \\ ${ }^{1,2}$ Program Studi Ilmu Komunikasi, Universitas Tribhuwana Tunggadewi \\ Email: putrymatau08@gmail.com
}

\begin{abstract}
Anak Langit soap opera is a soap opera broadcast by SCTV station produced by sinemart. The program is very popular with the audience, especially among teenagers who are still sitting on the school bench. This soap opera shows many events that are not educational to the audience such as scenes of violent acts in the form of brawls, reckless wild races on the highway and scenes of love outside the boundaries as school children. The focus of the problem that will be examined is the meaning of icons, indexes and symbols, and also forms of violence in the soap opera shows. In this study using qualitative research methods by collecting data through observation, interviews and documentation. The results of this study can be concluded that every scene that is in the soap opera child sky has a meaning that affects the assumptions for the community because not only adults who watch this program, but also many children who watch the show moreover this soap opera airing on primetime. These things tarnished the meaning of love in the soap opera anak langit.
\end{abstract}

Keywords: Soap Opera Anak Langit, Acts of Violence.

\begin{abstract}
Abstrak: Sinetron anak langit merupakan sinetron yang disiarkan oleh stasiun SCTV. Program acara ini sangat di gemari para penonton khususnya di kalangan remaja yang masih duduk dibangku sekolahan. Sinetron ini banyak menampilkan kejadian yang tidak mendidik untuk para penonton seperti adegan-adegan tindakan kekerasan berupa tawuran, balapan liar ugal-ugalan di jalan raya dan adegan percintaan di luar batas sebagai anak sekolah. Fokus masalah yang akan di teliti yakni makna ikon, indeks dan simbol, dan juga bentuk-bentuk kekerasan dalam tayangan sinetron anak langit. Dalam penelitian ini metode yang digunakan ialah metode penelitian kualitatif dengan pengumpulan data melalui observasi, wawancara dan dokumentasi.hasil dari penelitian ini menyimpulkan bahwa setiap adegan yang ada di dalam sinetron anak langit memiliki makna yang mempengaruhi asumsi bagi masyarakat karena tidak hanya orang dewasa yang menonton program acara ini,akan tetapi juga banyak anak-anak yang menonton tayangan tersebut terlebih lagi sinetron ini tayang pada waktu primetime. Hal-hal tersebut yang mencoreng makna dari kasih di dalam sinetron anak langit.
\end{abstract}

Kata kunci: Sinetron Anak Langit, Tindakan kekerasan.

\section{Pendahuluan}

Di era sekarang, media massa sangat berperan penting dalam kehidupan masyarakat. Hal itu tentu berbeda dengan kondisi tahun 1960-an di mana media massa masih belum cukup menarik untuk dibicarakan (Puji, 2016). Media massa semakin canggih dan kualitas media mengalami perkembangan yang sangat pesat, sehingga masyarakat semakin mudah mendapatkan informasi terbaru dan tercepat, bahkan media massa dapat melewati batas ruang dan waktu (Winarni, 2014). Membicarakan tentang media massa, maka kita juga berbicara mengenai komunikasi massa. Komunikasi massa berarti komunikasi melalui media massa, dengan rincian komunikasi adalah interaksi sosial melalui pesan, sedangkan massa adalah sekelompok orang dalam jumlah banyak (Morissan, Wardhani \& Hamid, 2010). Dengan demikian, media massa adalah jembatan komunikasi yang diarahkan kepada orang banyak (Krisnawati, 2016, Shahreza, 2017). 


\section{Jurnal Komunikasi Nusantara}

ISSN. 2685-7650

Vol. 1 No. 1 (2019)

Dari sekian banyak media massa yang ada, televisi menjadi media yang memiliki posisi paling tinggi dan menjadi media yang cukup popular di kalangan masyarakat (Azmi, 2014). Seiring dengan perkembangan teknologi serta daya kemampuan masyarakat dalam hal finansial, televisi dapat dihadirkan di setiap rumah. Hal ini terjadi karena media massa (televisi) menyediakan dan menciptakan realitas sosial baru yang belum ada sebelumnya, atau memberi arah baru pada kecenderungan yang sudah tercipta dan ada dalam masyarakat (Yudah, 2013). Media massa bahkan dianggap menyuguhkan gambaran yang fair tentang realitas dengan hanya sedikit distorsi (Krisdinanto, 2014). Oleh sebab itu, penggunaan televisi (media massa) membuka peluang yang sangat besar bagi masyarakat dalam memilih informasi yang beragam dan berbagai program atau saluran (Hafiar et al., 2014).

Dalam perkembangannya, media massa khususnya televisi lebih banyak menayangkan acara-acara yang lebih mengutamakan unsur hiburan. Para penonton harus lebih efektif dalam menonton dan memilih program acara yang di tayangkan. Beragam stasiun televisi di Indonesia dan salah satunya yaitu stasiun SCTV yang selalu menampilkan berbagai hiburan untuk para penonton. Salah satu sinetron unggulan SCTV yang mengangkat kisah kehidupan remaja, yaitu "Sinetron Anak Langit" yang ceritanya mirip bahkan para aktrisnya pun sama dengan pendahulunya di stasiun RCTI yaitu “Anak Jalanan” yang sering menampilkan adegan-adegan tentang kekerasan geng motor.

Sinetron Anak Langit sendiri sebenarnya merupakan sekuel spiritual Anak Jalanan. Sinetron ini dikerjakan oleh salah satu produser yang sudah sangat terkenal di dunia perfilman anak negeri, Leo Susanto. Sinetron ini banyak menampilkan kejadian yang tidak mendidik untuk para penonton seperti tindakan kekerasan, tawuran, balapan liar, ugal-ugalan di jalan raya dan percintaan. Hal ini meresahkan bagi masyarakat karena tidak hanya orang dewasa yang menonton program acara ini tetapi juga anak-anak yang menonton tayangan tersebut terlebih lagi sinetron ini tayang pada waktu primetime. Di sisi lain adanya hal positif yang bisa dipetik dari tayangan sinetron ini yaitu suka menolong, suka memberi sedekah, rajin mengaji dan juga taat beribadah. Tetapi sisi negatifnyalah yang mencoreng sinetron Anak Langit.

Menanggapi masalah tersebut masyarakat merasa khawatir dengan acara geng motor tersebut karena tayangan tersebut menampilan kekerasan, kebut-kebutan di jalan, tawuran antar geng motor dan percintaan yang melewati batas sehingga tidak baik untuk ditonton. Sebenarnya telah ada aturan yang bisa menjadi acuan dan tidak boleh dilanggar. Aturan yang dimaksud adalah UU Penyiaran No.32/2002 pasal 36 ayat 5 disebutkan, isi siaran dilarang menonjolkan unsur kekerasan, cabul, perjudian, penyalahgunaan narkotika dan obat terlarang. Bentuk kekerasan yang diatur dalam Standar Program Siaran (SPS) pasal 23 menyatakan bahwa adegan kekerasan dilarang menampilkan secara detail peristiwa kekerasan seperti tawuran, pengroyokan, penyiksaan, perang, penusukan, penyembelihan, mutilasi, terorisme, pengrusakan barang barang secara kasar, pembacokan dan bunuh diri.

\section{Metode Penelitian}

Penelitian ini menggunakan jenis penelitian kualitatif dengan pendekatan analisis semiotik model Charles Sanders Peirce. Jenis dan sumber data yang digunakan adalah data primer dan data sekunder. Menurut Lofland (dalam Lexy, 2014), sumber data utama dalam 


\section{Jurnal Komunikasi Nusantara}

ISSN. 2685-7650

Vol. 1 No. 1 (2019)

penelitian kualitatif ialah kata-kata dan tindakan, selebihnya adalah data tambahan seperti dokumen dan lain-lain. Data primer adalah data yang diperoleh dari soft file video berupa film atau sinetron "Anak Langit Episode 1, 2 dan 3". Kemudian dipilih visual atau gambar dari adegan-adegan sinetron yang diperlukan untuk penelitian. Data Sekunder adalah data yang diperoleh dari literatur-literatur yang mendukung data primer, berupa dokumen tertulis, yaitu seperti referensi film "Anak Langit”, baik dari artikel di internet maupun buku-buku yang relevan dengan penelitian.

Teknik pengumpulan data dalam penelitian ini yaitu dokumentasi. Dokumen ialah setiap bahan tertulis ataupun film, lain dari record, yang tidak dipersiapkan karena adanya permintaan seorang penyidik. Teknik analisa data dalam penelitian ini yaitu teknik analisis semiotika Charles Sanders Peirce. Peirce mengembangkan teori segi tiga makna (triangel meaning) yang terdiri atas tanda (sign), objek (object) dan interpretan (interpretant).

\section{Hasil dan Pembahasan}

\section{Gambaran Umum Sinetron Anak Langit}

Anak Langit merupakan sebuah sinetron yang ditayangkan di SCTV dan juga merupakan lanjutan dari sinetron Anak Jalanan. Sinetron ini diproduksi oleh SinemArt. Pemain sinetron Anak Langit antara lain Stefan William, Ranty Maria, Ammar Zoni, Immanuel Caesar Hito, Nasya Marcella, Cemal Faruk Urhan, Raya Kitty, Mischa Chandrawinata, Marcella Daryanani, Dylan Carr, Hana Saraswati, Gerald Yohanes Putra, Angela Gilsha, Angga Putra, Al Fathir Muchtar, Mega Aulia dan Umar Lubis. Cerita sinetron Anak Langit hampir sama dengan sinetron Anak Jalanan yang mengangkat cerita mengenai geng motor, persahabatan dan percintaan. Yang berbeda hanyalah pemeran utama dari sinetron ini dan beberapa pemain lainnya.

Bergantinya sinetron Anak Jalanan ke Anak Langit tidak membuat sinetron ini kalah dengan Anak Jalanan, namun justru penonton setia dari sinetron Anak Jalanan menjadi penonton Anak Langit. Alasan dari penonton Anak Jalanan tetap menonton sinetron Anak Langit karena mereka mengatakan bahwa mereka tidak rela bahwa Anak Jalanan tamat atau berakhir, maka dari itu kehadiran Anak Langit sangat dinantikan oleh penonton setia Anak Jalanan.

\section{Sinopsis Sinetron Anak Langit}

Anak Langit menceritakan tiga anak motor, Al (Ammar Zoni), Andra (Immanuel Caesar Hito), dan Key (Cemal Faruk), yang tinggal di Panti Asuhan milik Babe Rozak (Fathir Muchtar) dan Nyak Ida (Mega Aulia). Al, Andra dan Key memiliki kepribadian yang berbeda tetapi saling melengkapi. Mereka tergabung dalam sebuah geng motor Rainbow.

Salah satu anggota Rainbow bernama Reno (Juan Christian) telah meninggal dan menitipkan adiknya, Vika (Ranty Maria), kepada Al. Seiring berjalannya waktu, Al menaruh hati pada Vika. Namun, Rimba (Dylan Carr) yang merupakan ketua geng motor Rainbow, yang tak lain adalah musuh besar Al, berusaha menarik hati Vika. 


\section{Jurnal Komunikasi Nusantara}

ISSN. 2685-7650

Vol. 1 No. 1 (2019)

\section{Makna Ikon, Indeks dan Simbol dalam Sinetron Anak Langit}

Ikon adalah tanda yang mengandung kemiripan "rupa" sehingga tanda itu mudah dikenal oleh para pemakainya. Di dalam ikon, hubungan antara representamen dan objeknya terwujud sebagai kesamaan dalam beberapa kualitas. Contohnya, sebagian besar rambu lalu lintas merupakan tanda yang ironik karena "menggambarkan" bentuk yang memiliki kesamaan dengan objek yang sebenarnya.

Makna ikon dalam sinetron Anak Langit didefinisikan sebagai kondisi serta penggambaran situasi melalui cuplikan adegan yang ada, disesuaikan dengan permasalahan penelitian, yaitu mengenai bentuk kekerasan pada sinetron Anak Langit. Makna ikon di sini menggambarkan situasi ketika terjadi gejala atau bentuk kekerasan yang mungkin timbul, sedang timbul dan sudah timbul pada adegan sinetron. Sehingga peneliti menggambarkan ikon sebagai situasi awal yang terlihat tanpa memandang penyebab terjadi permasalahan serta kondisi lanjutan yang terjadi.

Indeks adalah tanda yang memiliki keterkaitan fenomenal atau eksistensial di antara representamen dan objeknya. Di dalam indeks, hubungan antara tanda dan objeknya bersifat konkret, aktual, dan biasanya melalui suatu cara yang sekuensial atau kausal (mengisyaratkan). Contohnya, jejak telapak kaki di atas permukaan tanah, indeks dari kehadiran seseorang. Ketukan pintu merupakan indeks dari kehadiran seorang tamu di rumah kita.

Makna indeks dalam sinetron Anak Langit didefinisikan sebagai gambaran kondisi permasalahan yang ada serta penyebab dan penjabaran sedikit terhadap situasi yang muncul. Indeks sedikit mirip dengan ikon namun dilengkapi dengan penyebab serta penggambaran umum yang terjadi pada adegan sinetron. Indeks juga diartikan sebagai analisis lanjutan setelah asumsi awal melihat cuplikan sinetron Anak Langit.

Simbol adalah jenis tanda yang bersifat arbitrer dan konvensional sesuai kesepakatan atau konvensi sejumlah orang atau masyarakat yang sudah lazim digunakan. Tanda-tanda kebahasaan pada umumnya adalah simbol-simbol. Tidak sedikit dari rambu lalu lintas yang bersifat simbolik.

Makna simbol dalam sinetron Anak Langit didefinisikan sebagai penjabaran dan penjelasan mengenai ungkapan dialog atau adegan yang memunculkan titik topik pembicaraan serta permasalahan yang menyebabkan adanya indikasi dan gejala bentuk kekerasan baik itu berupa ungkapan, ucapan maupun tindakan serta aksi nyata yang terlihat jelas dalam adegan. Simbol diartikan juga sebagai pandangan peneliti mengenai hal yang seharusnya tidak patut diucapkan atau dilakukan di dalam adegan sinetron Anak Langit, serta pendapat peneliti mengenai dampak yang dihasilkan dari permasalahan tersebut.

\section{Bentuk Kekerasan dalam Sinetron Anak Langit}

Ungkapan Kasar Kepada Orang yang Lebih Tua

Dari berbagai percakapan dan dialog yang terjadi dalam sinetron Anak Langit, peneliti berhasil menangkap dan menganalisis ungkapan kasar yang sepatutnya tidak perlu diungkapkan dalam hal ini ungkapan kasar kepada orang yang lebih tua. Hal ini terlihat beberapa kali dalam adegan sinetron Anak Langit. Ungkapan yang diberikan seperti "Aki-aki tua bangka" yang berarti menggambarkan kondisi pria tua renta yang tidak mampu berbuat 


\section{Jurnal Komunikasi Nusantara}

ISSN. 2685-7650

Vol. 1 No. 1 (2019)

apa-apa dengan nada dan gaya bicara yang kuat dan kasar. Membuat makna ungkapan ini seperti hinaan dan cacian kepada orang yang lebih tua. Hal tersebut merupakan ucapan yang kurang baik untuk didengar dan dianggap kurang sopan terlebih yang mengucapkan adalah seorang pria dengan usia yang lebih muda. Hal ini tentu menjadi budaya yang tidak dibenarkan di Indonesia, karena orang-orang yang lebih tua harusnya tidak mendapat julukan dengan perkataan yang cukup kasar seperti itu. Hal tersebut sangat disayangkan oleh peneliti dalam adegan sinetron Anak Langit.

Selanjutnya nada bicara membentak kepada orang yang lebih tua juga ditampilkan secara nyata dalam adegan sinetron Anak Langit. Ucapan "Heh!" dengan menunjuk kepala orang yang lebih tua merupakan budaya dan norma serta etika yang kurang baik di Indonesia sebagai negara yang menjunjung tinggi budaya Timur.

\section{Ungkapan Menghina Status Sosial dan Asal Usul Seseorang}

Ungkapan kekerasan lainnya adalah berupa adanya bentuk ungkapan yang sebenarnya digunakan untuk menggambarkan status sosial seseorang seperti "anak kampung”. Ungkapan "anak kampung" dalam arti sesungguhnya adalah kehidupan seorang anak yang berasal dan tinggal di daerah pedesaan. Dalam konteks identitas anak yang tinggal di kampung memang tidak menjadi masalah. Namun yang dimaksud dalam adegan di atas adalah "anak kampung" menjadi sebutan atau julukan untuk menggambarkan seseorang yang tidak memiliki status sosial. Artinya sebutan "anak kampung” dianggap sebagai sebutan untuk kaum rendahan dan tidak bermartabat. Ucapan seperti ini merupakan ucapan yang dirasa cukup kasar, terlebih atas maksud dan tujuan ucapan tersebut dikeluarkan dari mulut seseorang.

Anak kampung merupakan identitas seorang anak yang tinggal di daerah pedesaan, bukan dijadikan sebagai ucapan ejekan untuk menggambarkan status sosial. Hal ini dirasa kurang baik untuk diucapkan di tayangan televisi apalagi ditonton oleh jutaan masyarakat. Hal tersebut terlihat memiliki makna yang indah, namun apabila digunakan dengan maksud lain dan dengan nada yang kasar maka makna yang dihasilkan juga berbeda, yaitu menggambarkan status sosial yang dianggap kuno, norak dan sebagainya.

Hal lain adalah ungkapan menghina asal usul seseorang seperti ungkapan "anak pungut". Pungut merupakan kata kerja yang digunakan untuk mengambil "benda mati atau barang" dan bukan manusia atau seseorang dari suatu tempat. Ungkapan "anak pungut" sama artinya dengan "anak yatim piatu" yang dibesarkan oleh bukan orang tua kandung. Ungkapan anak yatim piatu terdengar sangat halus dan bisa diterima oleh masyarakat, namun ungkapan "anak pungut" terdengar sangat kasar dan tidak etis. Terlebih dapat menyakiti dan menyinggung perasaan orang lain khususnya anak-anak dengan kondisi serupa. Hal tersebut sepatutnya tidak diucapkan terlebih dengan nada yang keras dan diucapkan di depan umum. Bagi anak-anak yang terlahir dan dibesarkan oleh orang tua kandung mungkin tidak ada masalah. Akan tetapi apabila didengar oleh anak yatim piatu, atau anak yang dirawat oleh orang tua angkat tentu akan tersinggung. Karena "anak pungut" seperti ungkapan mengambil benda mati di suatu tempat antah berantah dan hanya dipungut tanpa ada makna. Ungkapan "anak pungut" terdengar tidak enak di telinga dan terkesan sangat kasar serta dapat menyinggung 


\section{Jurnal Komunikasi Nusantara}

ISSN. 2685-7650

Vol. 1 No. 1 (2019)

orang lain yang merasa "seperti itu" khususnya anak-anak sehingga dapat menyakiti hati mereka.

\section{Adegan Perkelahian dan Pengeroyokan}

Hal ini merupakan bentuk kekerasan yang terlihat nyata dan dapat dirasakan serta dilihat langsung, yaitu adegan perkelahian serta pengeroyokan. Adegan ini memberikan contoh yang tidak baik lagi bagi penonton, khususnya anak-anak dan para remaja. Anak-anak dan remaja umumnya menyerap apa yang mereka lihat dan mereka rasakan. Adegan kekerasan berupa perkelahian dan pengeroyokan tentu memberikan pengaruh tersendiri bagi anak-anak dan remaja, terlebih kalau mereka sampai mengikuti adegan tersebut di kehidupan nyata. Tawuran pelajar, perkelahian antar sesama teman, saudara merupakan praktek yang dibayangkan oleh anak-anak dan remaja ketika diberikan contoh yang tidak baik oleh media massa melalui acara sinetron tersebut. Sinetron Anak Langit sebaiknya mengurangi ikon-ikon negatif yang menonjol di setiap adegannya, salah satunya seperti adegan perkelahian. Adegan perkelahian merupakan bentuk kekerasan fisik yang langsung terasa untuk seseorang. Sebaiknya untuk adegan televisi yang dilihat oleh banyak orang dapat menjaga norma dan etika pembuatan naskah serta adegan sinetron agar memberikan pendidikan serta hiburan dalam satu waktu tanpa menghilangkan norma dan adat yang sudah berkembang di Indonesia dalam waktu yang sangat lama.

\section{Ungkapan Menghina Status Sosial seseorang}

Ucapan "cewek kagak bener" merupakan istilah atau sebutan untuk menggambarkan seorang wanita yang memiliki kelakuan yang tidak baik atau nakal. Ungkapan "cewek kagak bener" sama halnya seperti mengungkapkan kata "gadis malam atau pelacur". Ucapan seperti itu merupakan penilaian seseorang yang cukup kasar terhadap seorang wanita yang ia anggap memiliki perilaku yang tidak sesuai norma atau etika. Padahal tidak semua yang dilihat sesuai dengan kenyataan. Bagi sebagian orang yang tidak paham, ungkapan tersebut mungkin tidak ada masalah. Namun bagi yang sudah memahami banyak ungkapan, ucapan tersebut dirasa cukup kasar untuk disebutkan dalam sebuah dialog. Penilaian yang belum tentu benar, membuat sebagian orang mengungkapkan kata-kata yang sebenarnya tidak pantas untuk diucapkan.

\section{Adegan Perkelahian Antar Geng Motor di Tempat Umum}

Perkelahian merupakan sesuatu yang identik dengan kekerasan. Adegan perkelahian sekaligus pengeroyokan untuk kedua kalinya ditunjukkan di adegan sinetron Anak Langit. Adegan ini memberikan contoh yang tidak baik lagi bagi penonton, khususnya anak-anak dan para remaja. Anak-anak dan remaja umumnya menyerap apa yang mereka rasakan. Adegan kekerasan berupa perkelahian dan pengeroyokan tentu memberikan pengaruh tersendiri bagi anak-anak dan remaja, terlebih kalau mereka sampai mengikuti adegan tersebut di kehidupan nyata. perkelahian antar sesama teman, saudara merupakan praktek yang dibayangkan oleh anak-anak dan remaja ketika diberikan contoh yang tidak baik oleh media massa melalui acara 


\section{Jurnal Komunikasi Nusantara}

ISSN. 2685-7650

Vol. 1 No. 1 (2019)

sinetron tersebut. Sinetron Anak Langit sebaiknya mengurangi ikon-ikon negatif yang menonjol di setiap adegannya, salah satunya seperti adegan perkelahian tersebut.

\section{Kesimpulan}

Makna ikon, indeks dan simbol merupakan penjelasan situasi secara bertahap sesuai dengan konteks dan kondisi yang ada. Ikon merupakan analisis tahap awal hanya melihat sisi yang tampak. Indeks merupakan analisis lanjutan dengan menjelaskan penyebab masalah dan simbol merupakan penjabaran atas titik permasalahan dan topik yang terjadi.

Bentuk kekerasan yang terjadi dalam sinetron Anak Langit kebanyakan berupa dua hal yaitu ucapan kasar dan tindakan yang kurang mendidik. Berbagai bentuk hinaan dan cacian serta berkurangnya norma penghormatan dan etika dalam menyampaikan suara serta adegan kekerasan berupa perkelahian dan pengeroyokan yang memberikan contoh yang tidak baik kepada penonton.

\section{Daftar Pustaka}

Azmi, N. (2014). Dampak Media Televisi Terhadap Prilaku Sosial Anak. Scientiae Educatia, 3(2), $11-28$.

Hafiar, H., Puspitasari, L., \& Anwar, R. K. (2014). Literasi Informasi Media: Studi Kasus Manfaat Media Massa Terhadap Difusi Inovasi Pertanian di Kecamatan Singaparna Kabupaten Tasikmalaya. Edulib, 1(1), 16-34. https://doi.org/10.17509/edulib.v4i1.1170

Krisdinanto, N. (2014). Anomali dan Teori Hirarki Pengaruh terhadap Isi Media. Komunikatif, 3(1), 1-18. https://doi.org/https://doi.org/10.33508/jk.v3i1.1243

Krisnawati, E. (2016). Perilaku Konsumsi Media oleh Kalangan Remaja Dalam Pencarian Informasi (Studi Kasus Perilaku Remaja di Kota Salatiga dalam Penggunaan Media Dalam Perspektif Teori Ketergantungan Media). KOMUNIKATIF, 5(1), 43-69. https://doi.org/https://doi.org/10.33508/jk.v5i1.923

Lexy, M. (2014). Metodologi Penelitian Kualitatif Edisi Revisi. PT. Bandung: Remaja Rosdakarya.

Morissan, Andy Corry Wardhani, F., \& Hamid. (2010). Teori Komunikasi Massa. Bogor: Ghalia Indonesia.

Puji, S. (2016). Konstruksi Sosial Media Massa. Al-Balagh, 1(1), 30-48.

Shahreza, M. (2017). Komunikator Politik Berdasarkan Teori Generasi. Nyimak (Journal of Communication), 1(1), 33-48. https://doi.org/10.31000/nyimak.v1i1.273

Winarni, L. (2014). Media Massa dan Isu Radikalisme Islam. Dalam Jurnal Komunikasi Massa, 7(2), $159-166$.

Yudah, A. A. P. (2013). Representasi Transgender dan Transeksual dalam Pemberitaan di Media Massa: Sebuah Tinjauan Analisis Wacana Kritis. Indonesian Journal of Criminology, 9(1), $37-49$. 